\title{
Determinants Of Mortgage Delinquency
}

\author{
William Brent, Howard University, USA \\ Lynne Kelly, Howard University, USA \\ Debby Lindsey-Taliefero, Howard University, USA \\ Russell Price, Howard University, USA
}

\begin{abstract}
This paper examines mortgage delinquency rates for loans in each state and Washington, DC from 2004 through 2009 in order to gain insight into the key factors that drive residential mortgage delinquency. Models are estimated for 30-day, 60-day, 90-day, 90+ day, and all delinquency rates. Prime and subprime loans are modeled separately in cross-sectional time series regressions. The findings suggest that borrower income, type of loan, and the general health of the economy remain important in determining delinquency risk. Also, factors that determine 30- and 60-day delinquency rates differ from those that determine 90-day and 90+ day delinquency rates. In addition, factors that determine prime delinquency rates differ from those that determine subprime delinquency rates. Finally, borrower race does not consistently explain delinquency rates.
\end{abstract}

Keywords: Real estate financing; foreclosures and mortgage lending

\section{INTRODUCTION}

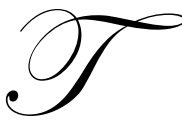

he issue of what drives default is at the core of residential mortgage default literature. Studies of mortgage default usually consider the completion of the foreclosure process. However, there are many steps between the time a borrower stops making payments and foreclosure. At each scheduled payment date, a borrower can choose to make the mortgage payment, delay payment, stop payments completely, or pay the balance of the loan through refinancing or sale of the property. A borrower is considered to be delinquent on his mortgage when one payment has been completely missed and a second payment is due. Once a borrower misses three or more payments, he is considered to have defaulted. Lenders may then proceed with foreclosure.

When scheduled payments are not made, lenders cannot know whether borrowers are only delaying mortgage payments temporarily or stopping mortgage payments altogether. Borrowers may choose to become delinquent on a mortgage to address cash flow problems resulting from a decline in income or an increase in expenses. Delinquency is costly to both borrowers and lenders. For borrowers, delinquency costs include penalty fees and a lower credit rating. For lenders, slow loans may be almost as costly as loans that reach foreclosure. Moreover, a loan must necessarily be delinquent prior to foreclosure. Therefore, identifying the factors that drive delinquency and the transition from delinquency to foreclosure is important.

This paper examines mortgage delinquency rates for loans in each state and Washington, DC from 2004 through 2009, a period characterized by sharp increases in borrower delinquency. The models incorporate information available to mortgage providers from the loan application about the borrower and the type of loan, as well as variables that capture economic conditions and shocks to income. The analysis provides information that will allow mortgage providers to improve assessments during underwriting and mortgage servicers to implement strategies that improve the default resolution process. The paper proceeds as follows. In the second section, we discuss determinants of mortgage delinquency. In the third section, we formulate an econometric model of mortgage delinquency rates. In the fourth section, we present data on mortgage delinquency rates across the US. In the fifth section, we present our empirical analysis. Our conclusions are presented in the sixth section. 


\section{DETERMINANTS OF MORTGAGE DELINQUENCY}

Most residential mortgage default studies focus on providing insight to the foreclosure risk of mortgages. There are relatively few studies on mortgage delinquency. Early studies of mortgage delinquency include Herzog and Earley (1970), von Furstenberg and Green (1974), Morton (1975) and Campbell and Dietrich (1983). These studies examine the relationship between delinquency and various loan and borrower characteristics.

Herzog and Earley (1970) find that loan-to-value ratio and the presence of junior financing have a positive effect on delinquency. Income stability, measured by type of occupation, significantly reduces delinquency. The term of the loan and payment-to-income ratio are found to have no affect on delinquency.

von Furstenberg and Green (1974) find loan-to-value ratio and the presence of junior financing to have a positive effect on delinquency. The authors also find an age pattern to delinquency. Delinquency rates increase after origination, peaking at about the fourth year, and then fall to about one-third of their initial level by the fifteenth year. Income is found to be negatively related to delinquency.

Morton (1975) argues that a majority of delinquencies are cured and shows that variables capturing home equity and a borrower's ability to pay are less systematically related to delinquency than to default.

Campbell and Dietrich (1983) consider possible borrower action at each point in time. Borrowers are assumed to select the action that yields the highest utility. In this framework, the authors compare the determinants of delinquency and default rates. The authors find that household income and interest rates are more influential than home equity in explaining delinquency. While they expected loan-to-value ratio to be less important for delinquency than for default, their results show that loan-to-value ratio positively affects both delinquency and default. The unemployment rate is shown to have a significant positive effect on delinquency and default rates.

Another approach to analyzing residential mortgage delinquency considers the impact of income and expense shocks on borrowers' decisions to delay mortgage payments. Webb (1982) examines potential delinquency using increases in mortgage payment-to-income ratio over time as a proxy. He finds that households headed by minorities or persons in occupations with high income variability are more likely to become delinquent. Also, mortgages with a high degree of variability in payments are more likely to become delinquent. The findings also suggest that high risk borrowers are consistently more likely to become delinquent than other borrowers, regardless of the variability in mortgage payments.

Later studies of mortgage delinquency and default extend the work of Campbell and Dietrich (1983) by analyzing mortgage delinquency and default as separate outcomes. These studies include Ambrose and Capone (1998), Capozza and Thomson (2005), Danis and Pennington-Cross (2005), and Capozza and Thomson (2006).

Ambrose and Capone (1998) track the ultimate resolution of a sample of FHA loans that are at least three months delinquent. The authors find that models that separate loans by their expected equity position at default are statistically different. These differences are attributed to "ruthless" versus "trigger event" defaulters. Ruthless defaulters increase their wealth by defaulting on a mortgage when there is negative equity in the property. Such defaults are termed ruthless in the sense that borrowers have the ability to pay but choose not to do so. Trigger event defaulters foreclose on their properties even though there is positive equity. In this case, the amount of equity does not exceed the cost of selling and the household does not have the liquid assets to make up the difference upon sale. These liquidity-constrained borrowers often have difficulties that arise from events such as job loss, illness, death, divorce, or jumps in mortgage payments because of interest rate resets on adjustable-rate mortgages (ARMs). The authors argue that subprime borrowers are more likely to be trigger event defaulters.

Capozza and Thomson (2005) provide evidence that subprime mortgage loans behave differently from prime loans. Subprime loans default earlier and the losses are larger than for prime loans.

Danis and Pennington-Cross (2005) examine the implications of delinquency on the performance of 30year, fixed rate subprime mortgages. They find that loans that are very delinquent prepay while those with negative 
equity default. The authors also find that credit scores are negatively related to delinquency and default. Unemployment rates are found to have no impact on delinquency or default rates.

Capozza and Thomson (2006) find that subprime lenders delay foreclosure proceedings for borrowers with weaker credit ratings and loans with higher interest rate premiums. Subprime loans that become seriously delinquent are about twice as likely as prime loans to foreclose, but they take four times longer to get there. Loans with shorter delinquency periods are more likely to cure.

In general, much of the research on the factors that drive mortgage delinquency is conducted on individual loans held in portfolios. Drawing from this literature, we model mortgage delinquency rates for loans in each state and Washington, DC for the period 2004 through 2009 using variables that can be classified into the following three categories: 1) borrower characteristics; 2) loan characteristics; and 3) economic conditions and shocks to income. The affect these variables have on delinquency rates is estimated in cross-sectional time-series regressions. Prime and subprime loans are modeled separately to capture differences in the performance of these loans.

\section{MODEL OF US MORTGAGE DELINQUENCY RATES}

We use a two-way fixed effects model to examine cross-sectional time series data on mortgage delinquency rates in the US. Our data consists of delinquency rates for all fifty states and Washington, DC for the period 2004 through 2009. Therefore, there are fifty-one cross-sectional observations and six time series observations. Greene (2003) expresses the two-way fixed effects model as follows:

$$
y_{i t}=\sum_{k=1}^{K} x_{i t k} \beta_{k}+u_{i t}
$$

$u_{i t}=\gamma_{i}+\alpha_{t}+e_{i t}$

where $y_{i t}$ is the dependent variable, $\beta_{k}$ represents the slope coefficients that are common to all cross-sections, $x_{i t}$ are the explanatory variables, $\gamma_{i} \mathrm{~s}$ are nonrandom parameters capturing the unobserved cross-sectional effects, $\alpha_{t} \mathrm{~s}$ are nonrandom parameters capturing the unobserved time effects, and $e_{i t}$ are the residuals which are independent and identically distributed random variables with $E\left[e_{i t}\right]=0$ and $E\left[e_{i t}^{2}\right]=\sigma_{e}^{2}$.

Since the dataset is balanced, we can write the following:

$$
\tilde{y}_{i t}=y_{i t}-\bar{y}_{i .}-\bar{y}_{. t}+\bar{y}
$$

$\tilde{x}_{i t}=x_{i t}-\bar{x}_{i .}-\bar{x}_{. t}+\bar{x}$

where the symbols:

$y_{i t}$ and $x_{i t}$ are the dependent variable (a scalar) and the explanatory variables (a vector whose columns are the independent variables not including a constant), respectively.

$\bar{y}_{i}$ and $\bar{x}_{i \text {. }}$ are cross section means.

$\bar{y}_{\cdot t}$ and $\bar{x}_{\cdot t}$ are time means.

$\bar{y}$ and $\bar{x}$ are the overall means. 
The two-way fixed effects model is simply a regression of $\tilde{y}_{i t}$ on $\tilde{x}_{i t}$. Therefore, the two-way $\beta$ is given by:

$$
\tilde{\beta}_{S}=(\tilde{X} \tilde{X})^{-1} \tilde{X} \tilde{y}
$$

The calculations of cross section dummy variables, time dummy variables, and intercepts follows. Denote the cross-sectional effects by $\gamma$ and the time effects by $\alpha$. These effects are calculated from the following relations:

$$
\begin{aligned}
& \hat{\gamma}_{i}=\left(\bar{y}_{i .}-\bar{y}\right)-\tilde{\beta}_{S}\left(\bar{x}_{i .}-\bar{x}\right) \\
& \hat{\alpha}_{t}=\left(\bar{y}_{. t}-\bar{y}\right)-\tilde{\beta}_{S}\left(\bar{x}_{. t}-\bar{x}\right)
\end{aligned}
$$

Denote the cross-sectional dummy variables and time dummy variables with the superscript $\mathrm{C}$ and $\mathrm{T}$. When no intercept is specified, the dummy equations can be written as follows:

$D_{i}^{C}=\hat{\gamma}_{i}+\hat{\alpha}_{T}$

$D_{t}^{T}=\hat{\alpha}_{t}-\hat{\alpha}_{T}$

The sum of squared errors is:

$$
S S E=\sum_{i=1}^{N} \sum_{t=1}^{T_{i}}\left(y_{i t}-\gamma_{i}-\alpha_{t}+X_{S} \tilde{\beta}_{S}\right)^{2}
$$

The estimated error variance can be written:

$$
\hat{\sigma}_{e}^{2}=S S E /(M-N-T-(K-1))
$$

The variance covariance matrix of $\tilde{\beta}_{S}$ is given by

$$
\operatorname{Var}\left[\tilde{\beta}_{S}\right]=\hat{\sigma}_{e}^{2}\left(\tilde{X}_{S}^{\prime} \tilde{X}_{S}\right)^{-1}
$$

The variance covariance matrix of the dummy variables is specified as follows:

$$
\begin{aligned}
& \operatorname{Var}\left[D_{i}^{C}\right]=\hat{\sigma}_{e}^{2}\left(\frac{1}{T}+\frac{1}{N}-\frac{1}{N T}\right)+\left(\bar{x}_{i \cdot}+\bar{x}_{\cdot t}-\overline{\bar{x}}\right)^{\prime} \operatorname{Var}\left[\tilde{\beta}_{s}\right]\left(\bar{x}_{i \cdot}+\bar{x}_{\cdot t}-\bar{x}\right) \\
& \operatorname{Var}\left[D_{t}^{T}\right]=\frac{2 \hat{\sigma}_{e}^{2}}{N}+\left(\bar{x}_{\cdot t}-\bar{x}_{T}\right)^{\prime} \operatorname{Var}\left[\tilde{\beta}_{S}\right]\left(\bar{x}_{\cdot t}-\bar{x}_{\cdot T}\right)
\end{aligned}
$$




$$
\begin{aligned}
& \operatorname{Cov}\left[D_{i}^{C}, D_{j}^{C}\right]= \hat{\sigma}_{e}^{2}\left(\frac{1}{N}-\frac{1}{N T}\right)+\left(\bar{x}_{m} i i \cdot+\bar{x}_{m} i \cdot t-\bar{x}\right)^{\prime} \operatorname{Var}\left[\tilde{\beta}_{s}\right] \\
&\left(\bar{x}_{m} i j \cdot+\bar{x}_{m} i \cdot t-\bar{x}\right) \\
& \operatorname{Cov}\left[D_{t}^{T}, D_{u}^{T}\right]= \frac{\hat{\sigma}_{e}^{2}}{N}+\left(\bar{x}_{\cdot t}-\bar{x}_{\cdot T}\right)^{\prime} \operatorname{Var}\left[\tilde{\beta}_{S}\right]\left(\bar{x}_{\cdot u}-\bar{x}_{\cdot T}\right) \\
& \operatorname{Cov}\left(D_{i}^{C}, D_{t}^{T}\right)=-\frac{\hat{\sigma}_{e}^{2}}{N}+\left(\bar{x}_{i \cdot}+\bar{x}_{. t}-\bar{x}\right) \operatorname{Var}\left[\tilde{\beta}_{S}\right]\left(\bar{x}_{. t}-\bar{x}_{. T}\right) \\
& \operatorname{Cov}\left[D_{i}^{C}, \beta\right]=-\left(\bar{x}_{i \cdot}+\bar{x}_{\cdot t}-\bar{x}\right)^{\prime} \operatorname{Var}\left[\tilde{\beta}_{s}\right] \\
& \operatorname{Cov}\left(D_{i}^{T}, \beta\right)=-\left(\bar{x}_{. t}-\bar{x}_{. T}\right)^{\prime} \operatorname{Var}\left[\tilde{\beta}_{S}\right]
\end{aligned}
$$

\section{DATA}

The data on delinquency rates are from the Mortgage Bankers Association National Delinquency Survey and are for the period 2004 through 2009. Figure 1 shows delinquency rates for all prime loans and those that are categorized as 30-day, 60-day, 90-day, and seriously delinquent (90+ day). During the sample period, delinquency rates for prime loans increased from 2.4 percent to 5.6 percent - a 130 percent increase. The largest increase occurred between 2008 and 2009. This rapid one-year increase in delinquency rates was driven by loans that were 90-day and seriously delinquent.

Figure 1: Delinquency Rates for Prime Mortgage Loans

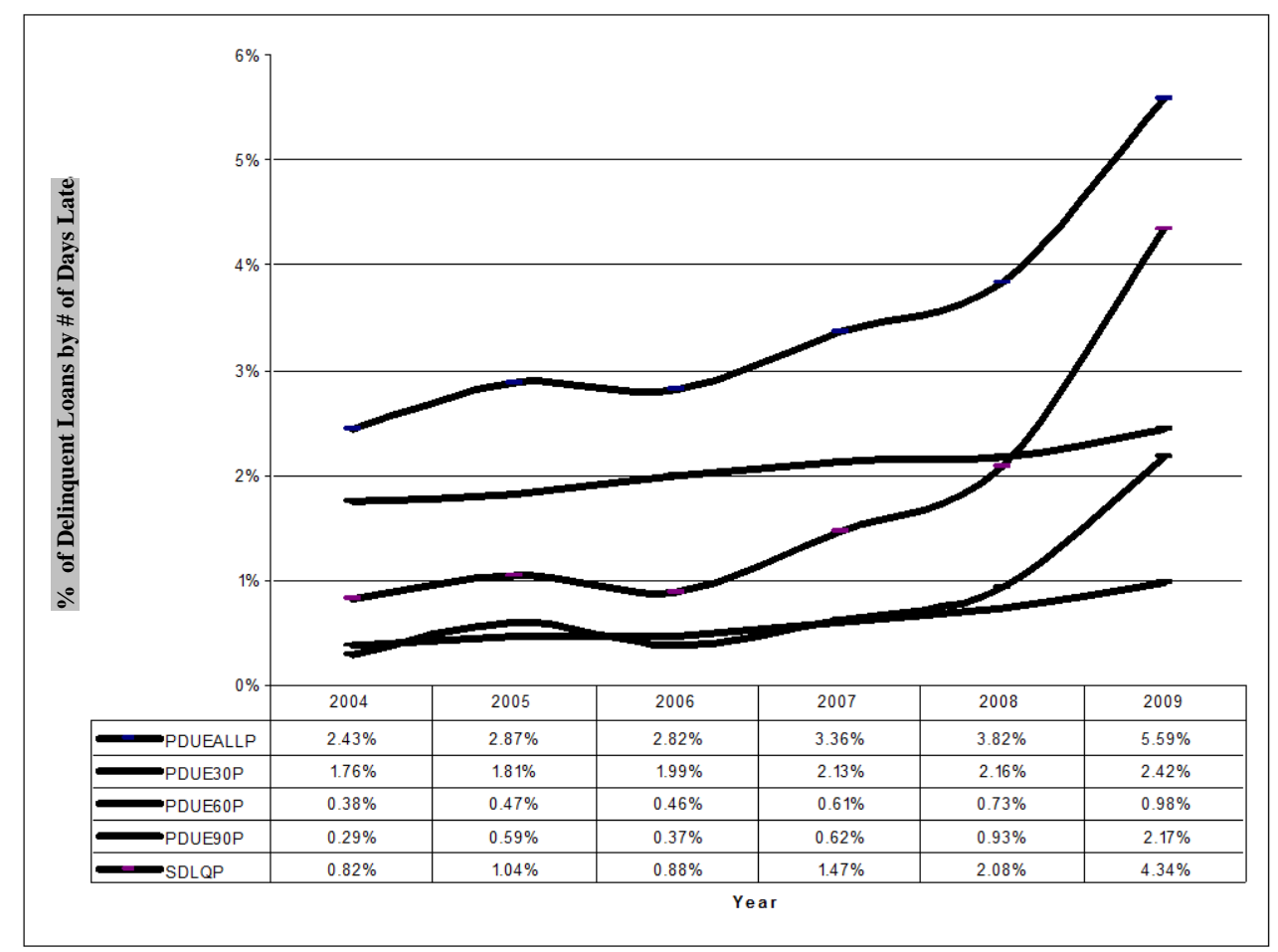


Figure 2 shows delinquency rates for all subprime loans and those that are categorized as 30-day, 60-day, 90-day, and seriously delinquent. During the sample period, delinquency rates for subprime loans are four to five times those for prime loans. Subprime delinquency rates increased from 11.0 percent in 2004 to 24.6 percent in 2009 - a 124 percent increase. Large increases in delinquency rates occurred during the periods 2006-2007 and 2008-2009 and were driven by loans that were 90-day and seriously delinquent.

Figure 2: Delinquency Rates for Subprime Mortgage Loans

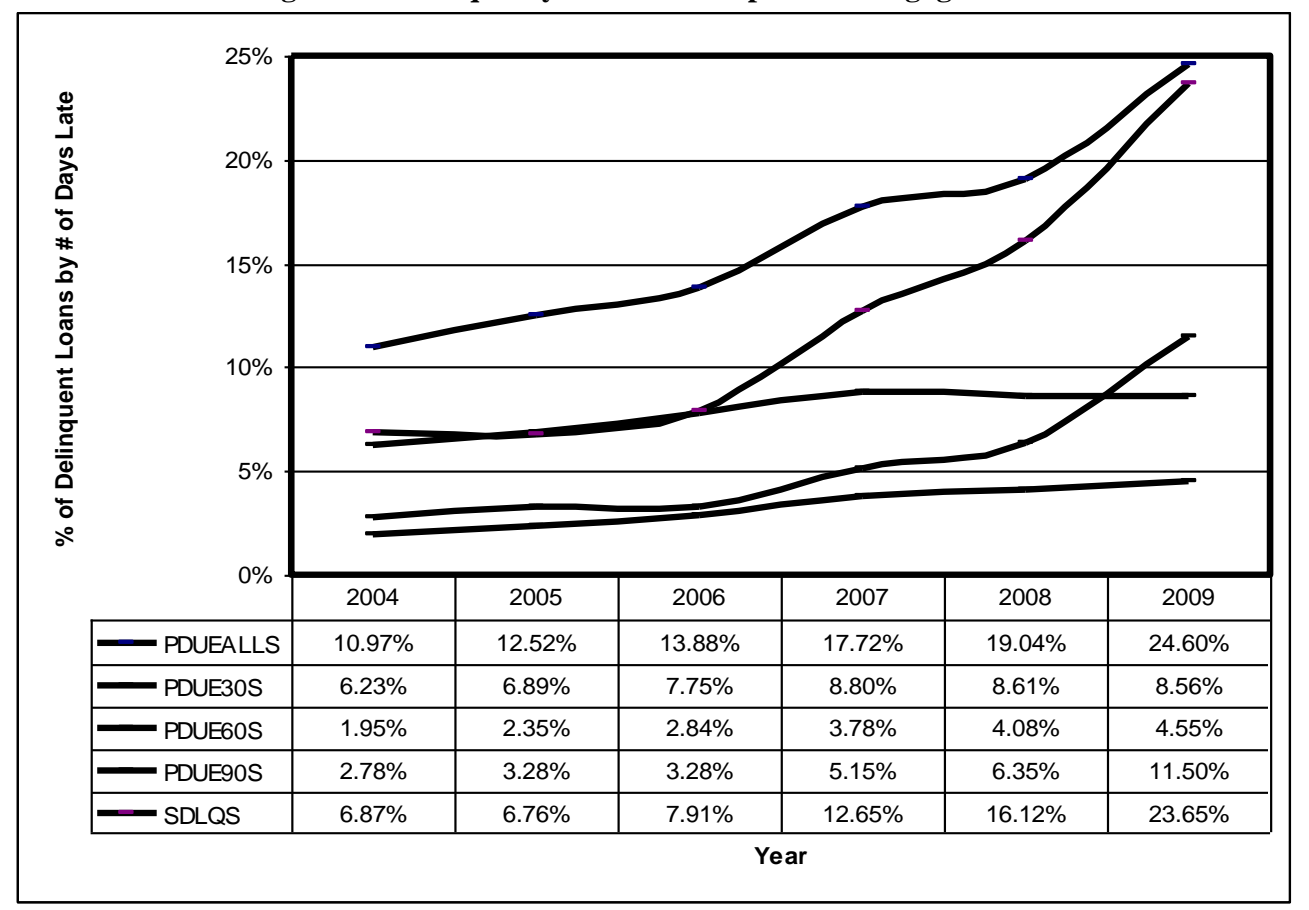

The explanatory variables used to estimate delinquency rates for each state and the proposed direction of influence are provided in Table 1. A trend analysis for each independent variable is provided in the paragraphs that follow.

Table 1: Dependent Variable, Delinquency Rate

\begin{tabular}{|c|c|c|c|}
\hline \multirow[t]{2}{*}{ Independent Variables } & \multirow{2}{*}{$\begin{array}{c}\text { Category } \\
\text { Borrower Characteristics }\end{array}$} & \multicolumn{2}{|c|}{ Direction of Influence } \\
\hline & & Direct (+) & Inverse (-) \\
\hline whpct, blpct, hispct, asnpct, \& ntvpct & borrowers by race $(\%)$ & $\mathrm{X}$ & $\mathrm{X}$ \\
\hline fempct & female borrowers $(\%)$ & $\mathrm{X}$ & \\
\hline credscr & credit score (\#) & & $\mathrm{X}$ \\
\hline income & personal income (current \$) & & $\mathrm{X}$ \\
\hline & Loan Characteristics & & \\
\hline nonoccpt & non-owner occupied loans (\%) & $\mathrm{X}$ & \\
\hline nivst & no-income verification loans $(\%)$ & $\mathrm{X}$ & \\
\hline spread & loans with a reportable rate spread at origination $(\%)$ & $\mathrm{X}$ & \\
\hline pctrefi & refinance loans $(\%)$ & & $\mathrm{X}$ \\
\hline lien2nd & loans with subordinate liens (\%) & $\mathrm{X}$ & \\
\hline pctadj & adjustable rate loans $(\%)$ & $\mathrm{X}$ & \\
\hline & Economic Conditions and Shocks to Income & & \\
\hline denpct & denial rate $(\%)$ & & $\mathrm{X}$ \\
\hline unempl & unemployment rate $(\%)$ & $\mathrm{X}$ & \\
\hline numpermt & number of building permits (\#) & & $\mathrm{X}$ \\
\hline hpidx & house price index (thousands \$) & & $\mathrm{X}$ \\
\hline probusvc & $\begin{array}{l}\text { growth rate of persons employed in professional and } \\
\text { business services }(\%)\end{array}$ & & $\mathrm{X}$ \\
\hline
\end{tabular}




\section{Borrower Characteristics}

Figure 3 captures race of the borrower in percent. Whpct, blpct, hispct, asnspct and ntvpct are the percent of white borrowers, African American borrowers, Hispanic borrowers, Asian borrowers, and Native American borrowers, respectively. The base category is "other". In general, loans to white borrowers are greater than 75 percent. These loans peaked in 2009 at 81.4 percent. African American borrowers' percent share of loans peaked in 2006 at 7.7 percent and steadily declined each year to 2.4 percent in 2009. Hispanic borrowers' percent share of loans also peaked in 2007 at 6.9 percent and declined to 2.9 percent in 2009. Asians' percent share ranged from 3.0 to 4.1 percent, peaking in 2009. Native Americans' percent share, in general, is less than one percent and ranged from 0.4 to 0.6 percent, peaking in 2004. The impact of borrower race on delinquency is expected to vary across race. Borrower race does not imply, for example, that being Hispanic will increase delinquency, but captures unobserved factors unique to being Hispanic that may influence delinquency. In some cases, minorities experience greater variation in income. This is expected to increase delinquency risk.

Figure 4 captures the percent of female borrowers - fempct. In view of the disparity in income between males and females, referred to as the "gender gap in earnings", it is assumed that females' ability to pay is impaired by the gap. As a result, being a female borrower should increase mortgage delinquency. The percent share of female borrowers has increased over time ranging from 6.9 to 7.3 percent.

Figure 5 captures credit score - credscr. Credit score is computed as a numerical expression based on a statistical analysis of a person's credit files. A credit score represents the creditworthiness of that person. Higher credit scores signify lower credit risk, and in turn, lower delinquencies. On average, the credit score for the United States was 678 in 2004, 677 in 2005, 676 in 2006, 692 in 2007, 683 in 2008 and 696 in 2009. The credit score data suggests that the overall trend in borrowers' creditworthiness has improved over time.

Figure 6 captures personal income in current dollars - income. Personal income includes earnings received from all sources, including rental income, dividend income, interest income, and transfer receipts. On average, personal income has increased steadily from 2004 to 2008 ranging from $\$ 32,336$ to $\$ 39,609$. In 2009 , personal income declined by 2.1 percent. It is assumed that individuals with higher incomes have fewer delinquencies.

Figure 3: Percent of Loans by Race

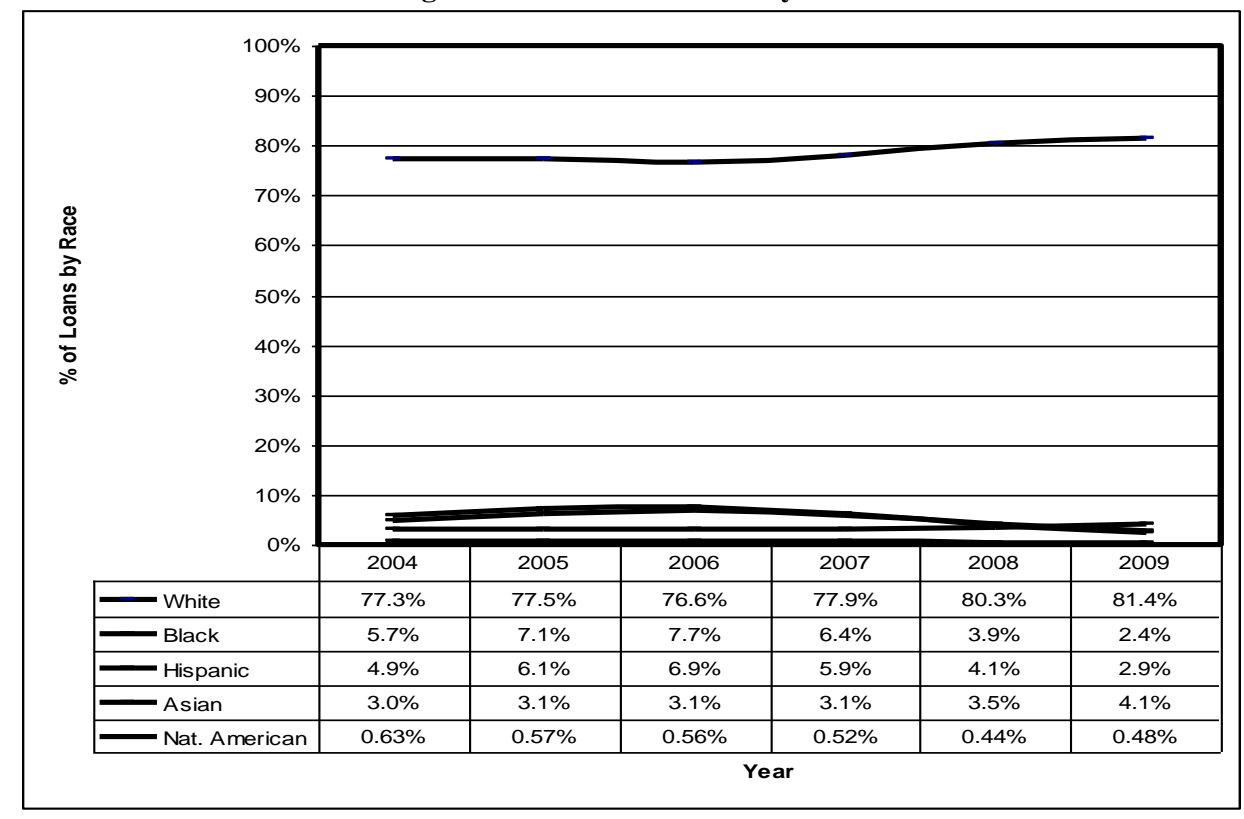


Figure 4: Percent of Loans by Females

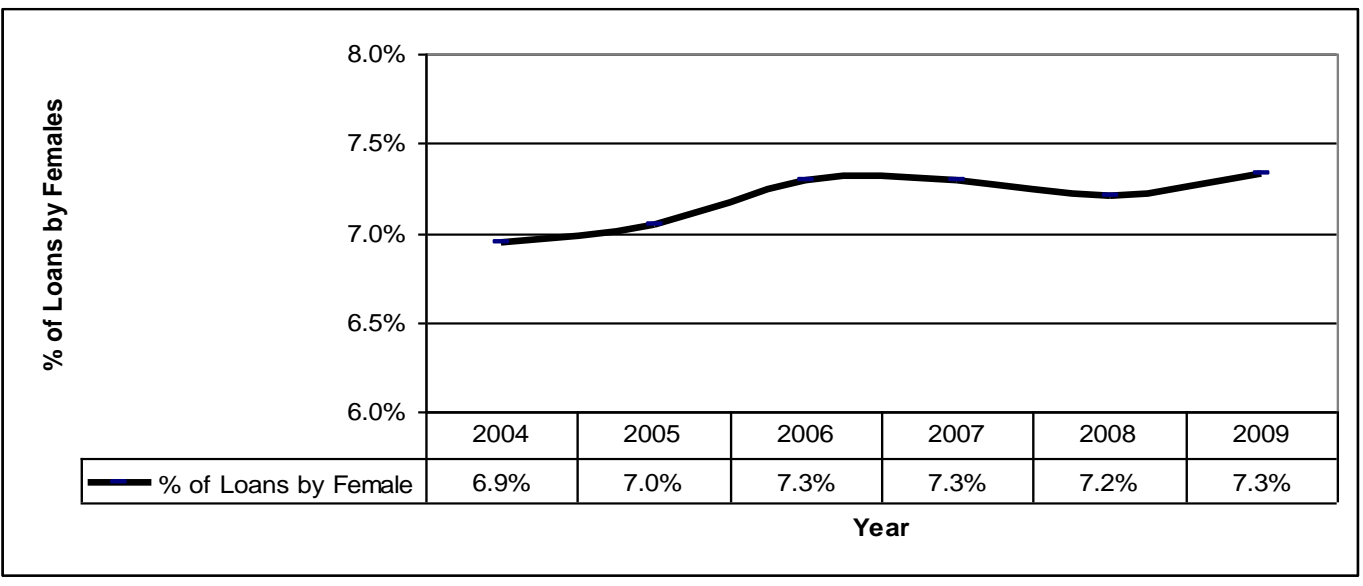

Figure 5: Average Credit Score

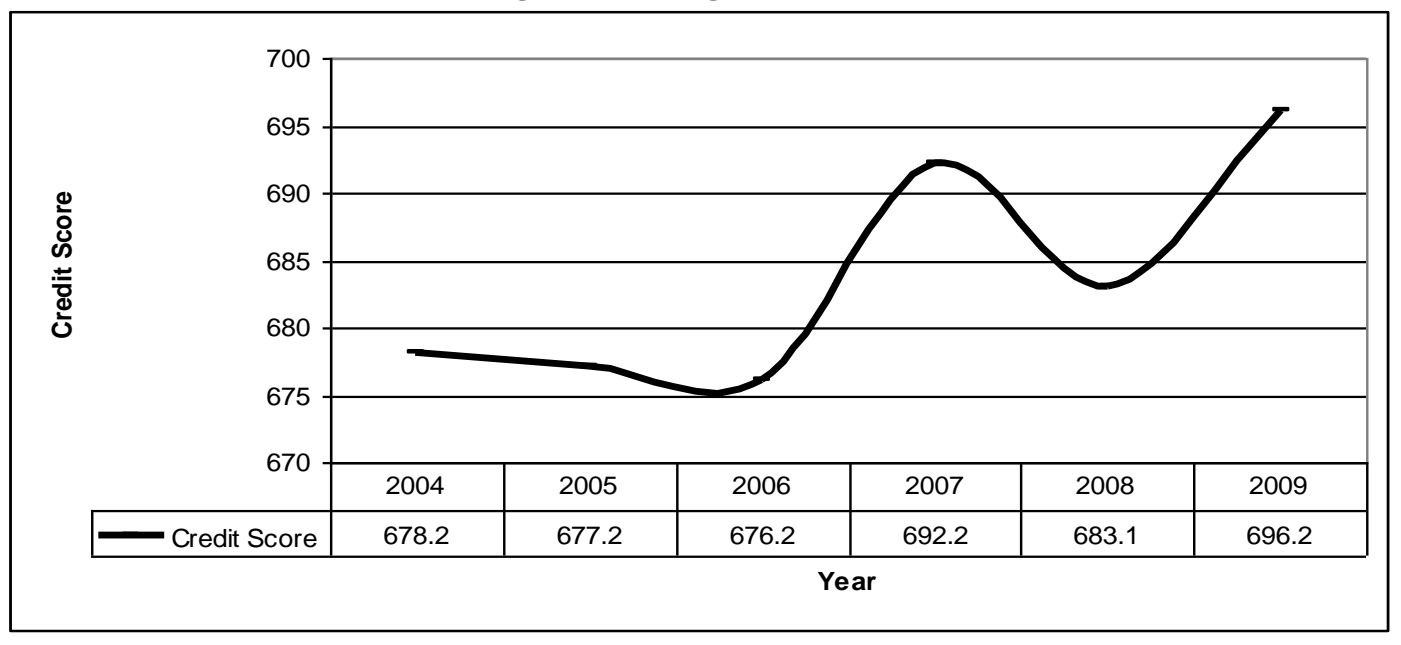

Figure 6: Personal Income

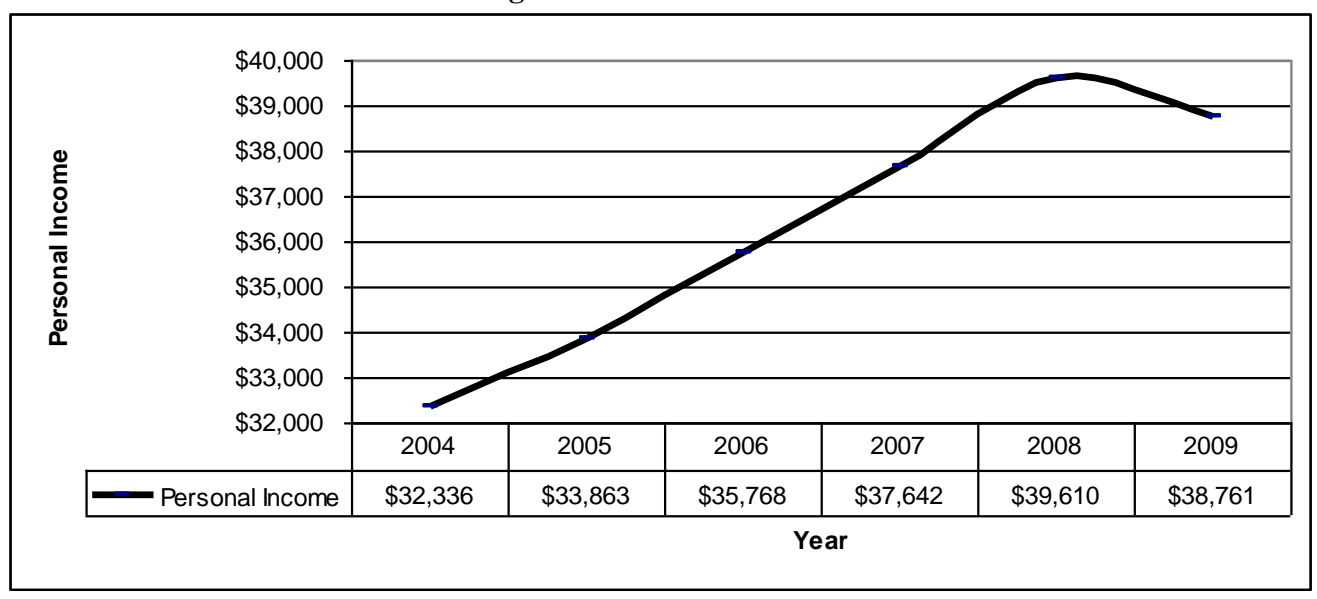




\section{Loan Characteristics}

Figure 7 captures the percent of loans where the borrower does not occupy the home - nonoccpt. Owner occupants are considered less risky and command the best terms, other things being equal. Non-owner occupants are considered to be real estate investors. Higher percentages of non-owner occupancy increase the chance of investor loan speculation and rental vacancy risk. This increases credit risk and delinquency. The percentage of non-owner occupant loans peaked in 2008 at 14.8 percent and declined to 9.2 percent in 2009.

Figure 8 captures the percent of loans in which income is not reported - nivst. While HMDA (Home Mortgage Disclosure Act) rules make no specific reference to NIV (No-Income Verification) applications per se, the NIV characteristic can be implicitly derived from the absence of a reported value in the income field. It is also assumed that NIV loans do not use income in the underwriting decision. The higher the percentage of NIV loans, then the higher the percentage of borrowers that may have insufficient income to support loan repayment, thereby increasing credit risk and delinquency. The percent of NIV loans peaked in 2006 and has declined since that time. There was a sharp decrease of 23.0 percent between 2007 and 2008.

Figure 9 captures the percent of loans with a spread at origination - spread. The spread is reported in HMDA if the difference between the annual percentage rate (APR) and the applicable Treasury yield is greater than or equal to 3 percentage points for first-lien loans or 5 percentage points for subordinate loans. A loan with a high spread indicates that the lender perceives the borrower has above-average risk. Therefore, loans with spreads are expected to have greater risk of delinquency. Between 2004 and 2005, the percent of loans with a spread increased by 64.8 percent. In 2006, loans with spreads peaked and then steadily declined by 36.9 percent, 40.8 percent, and 70.9 percent in 2007,2008 , and 2009 , respectively.

Figure 10 captures the percent of loans originated for refinancing a housing unit - pctrefi. The share of loans for refinancing declined in 2005 and 2006 by 10.2 percent and 3.4 percent, respectively. The refinance percentage increased sharply, by 72.0 percent, 15.2 percent, and 35.8 percent in 2007, 2008, and 2009, respectively. It is assumed that the ability to refinance, particularly out of a bad loan, will decrease delinquency. Also, it is assumed that borrowers that refinance mortgage loans have more experience handling mortgage payments. This should also reduce risk of delinquency.

Figure 11 captures the percent of loans originated that are secured by a subordinate lien on the dwelling lien2nd. Loans with subordinate liens are riskier for lenders and generally come with less favorable terms than first mortgages. In addition, secondary financing suggests that the loan-to-value ratio may be understated. This should increase risk of delinquency. The share of loans with second liens peaked in 2006 and declined dramatically since then. The percent of loans with second liens fell by 27.9 percent, 51.5 percent and 80.1 percent in 2007, 2008, and 2009 , respectively.

Figure 12 captures the percent of adjustable rate mortgages (ARMs) - pctadj. Adjustable rate mortgages have interest rate changes based on a standard rate index. Most ARMs have a cap on how much the interest rate may increase. The higher the percentage of ARMs, the greater the number of borrowers that are exposed to payment shocks. This increases credit risk and leads to higher delinquencies. Between 2004 and 2005, the percent of adjustable rate mortgages increased by 16.5 percent. The share of ARMs peaked at 17.3 percent in 2006 and declined by 3.6 percent, 9.3 percent, and 17.4 percent in 2007, 2008, and 2009, respectively. 
Figure 7: Percent of Non-occupancy Loans

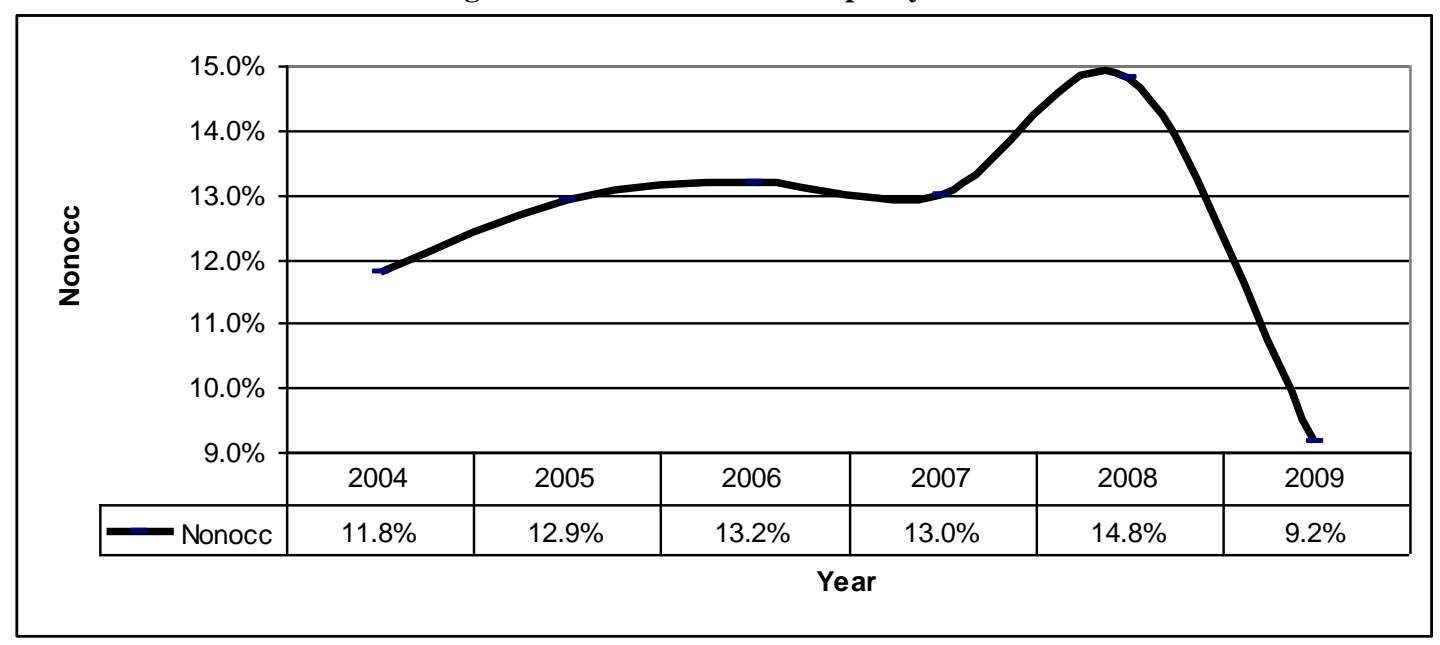

Figure 8: Percent of Loans with No-income Verification

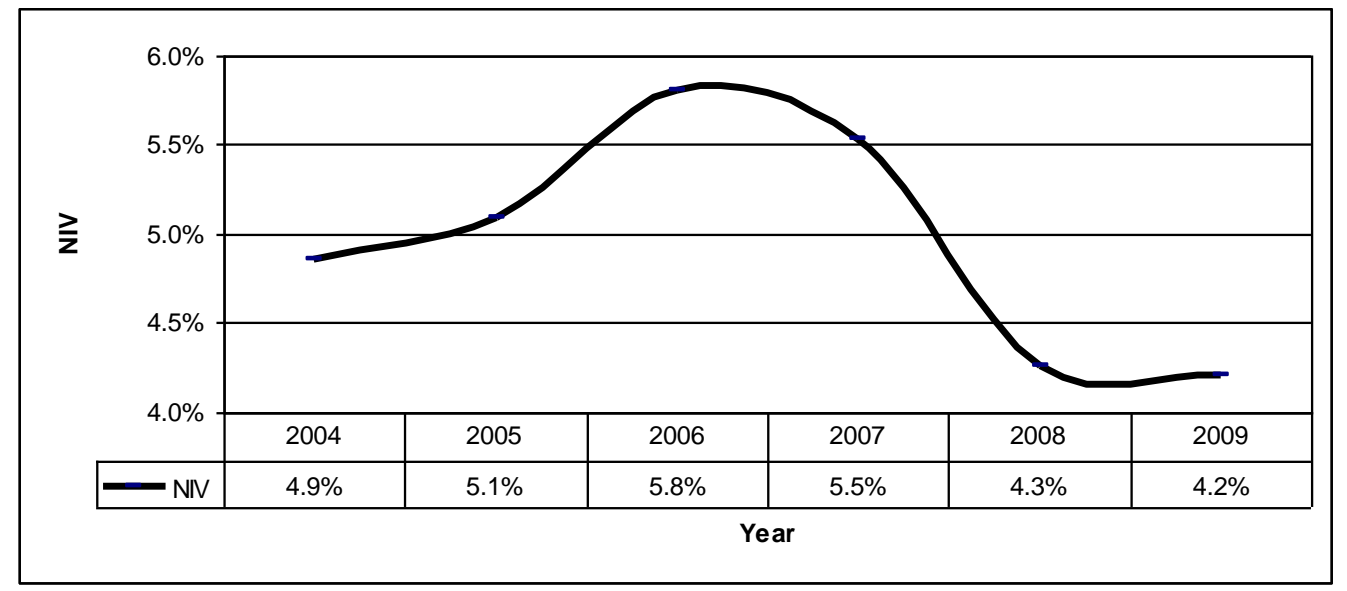

Figure 9: Percent of Loans with a Spread

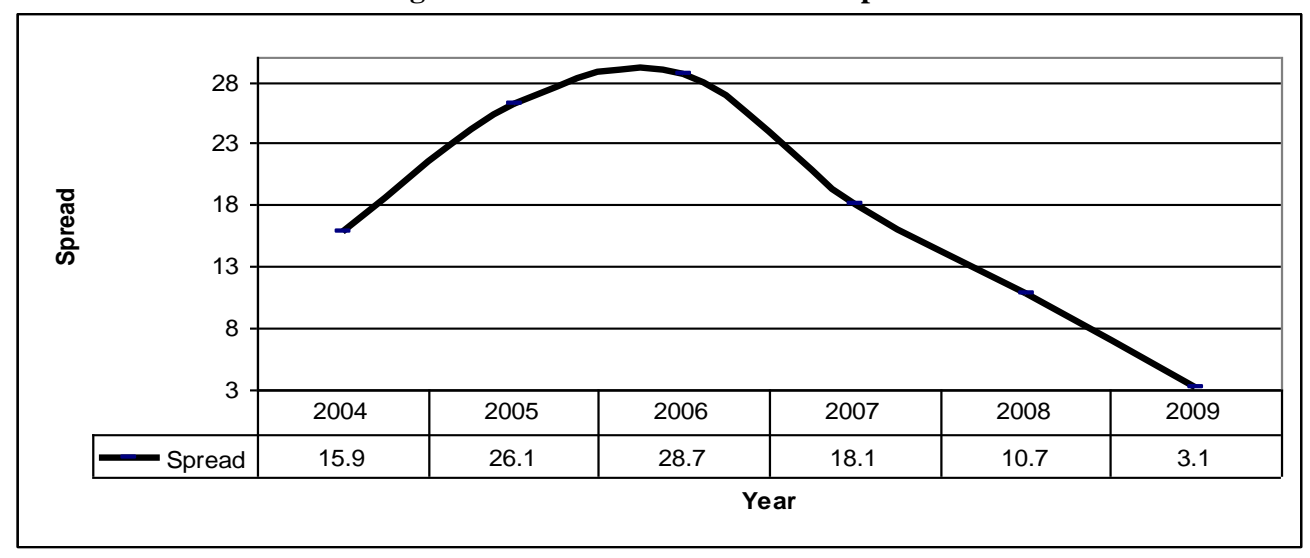


Figure 10: Percent of Refinanced Loans

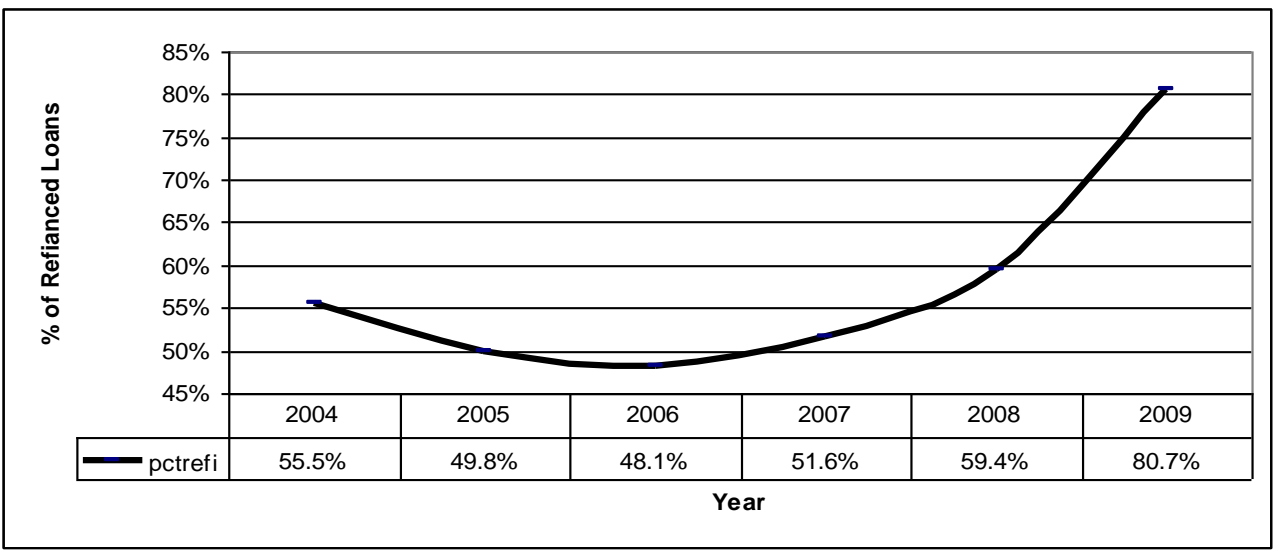

Figure 11: Percent of Loans with a Second Lien

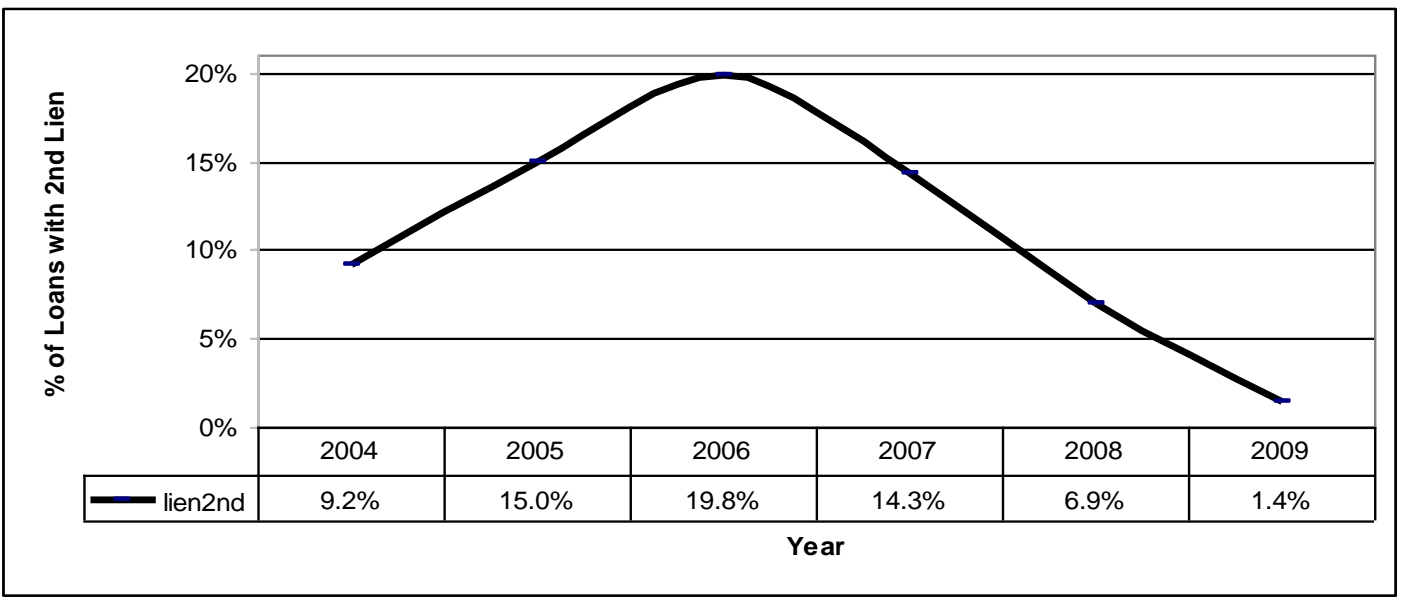

Figure 12: Percent of Adjustable Rate Loans

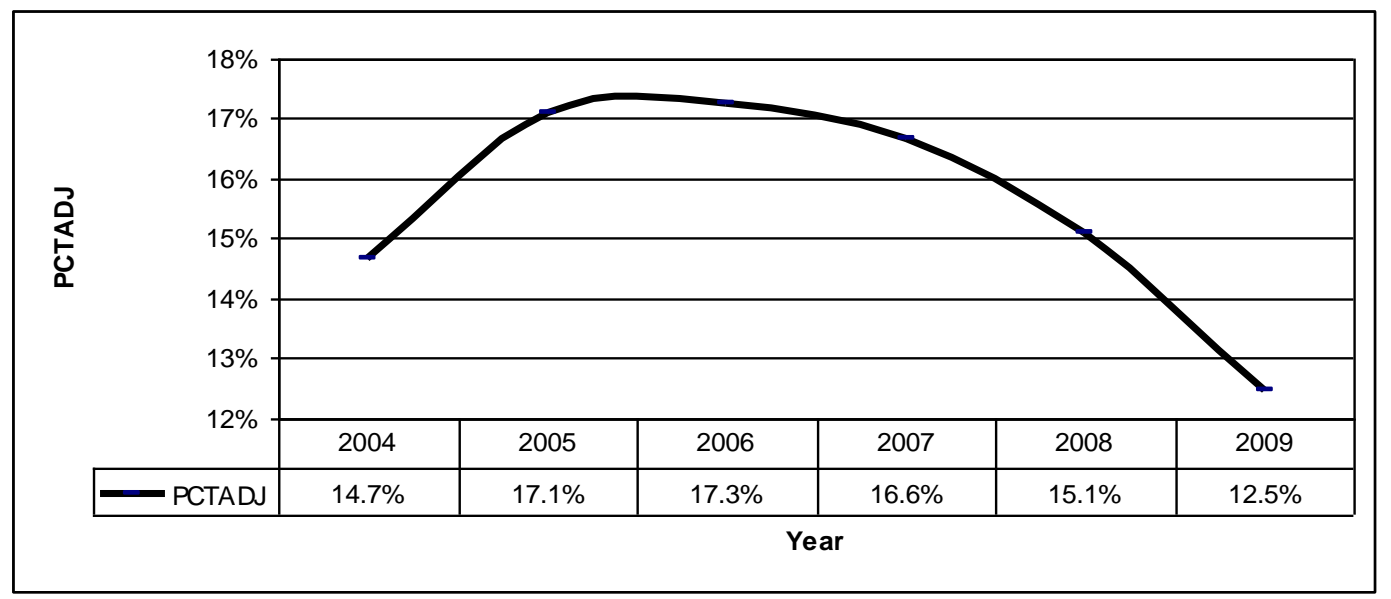

\section{Economic Conditions and Shocks to Income}

Figure 13 captures the percent of applications that were not approved - denpct. Higher denial rates suggest higher credit standards, lower credit risk, and lower defaults. There are, however, divergent patterns of denial rates 
for prime and subprime lenders. Subprime lenders attract many applications from less creditworthy individuals resulting in high denial rates. To the extent that this variable includes subprime activity, it may not have the inverse relationship on delinquency as expected. A direct relationship could exist because borrowers are finding it more difficult to obtain mortgage financing. In general, the percent of applications denied can serve as an indicator of the availability of mortgage credit, which is critical to a well functioning housing market. In 2007, the share of applications denied peaked at 24.7 percent. Denials experienced a sharp 19 percent decline in 2008 followed by a modest 3.2 percent decline the following year.

Figure 14 captures the unemployment rate - unempl. The unemployment rate declined between 2004 and 2007, then increased by 22 percent in 2008 and 58 percent in 2009 . Unemployment results in shocks to income that impact a borrower's ability to pay a mortgage. Therefore, unemployment rate and mortgage delinquency should be directly related.

Figure 15 captures the number of construction building permits which represent the number of new privately-owned housing units authorized to be built in the United States - numpermt. The number of building permits provides a general indication of the amount of new housing stock that has been added to the housing inventory. Since not all permits become actual housing starts and starts lag the permit stage of construction, these numbers do not represent total new construction, but should provide a general indicator of construction activity. Housing permits are issued in larger quantities when the housing market is expected to be strong. If a trigger event occurs, a borrower's ability to sell or refinance is likely to be better in a strong housing market. This should reduce the risk of delinquency. The number of permits peaked in 2005 and has progressively declined. The largest decline in permits - 41 percent - occurred in 2008. This downward trend in construction activity served as a barometer that the economy started to move into a recession.

Figure 16 captures the Freddie Mac Conventional Mortgage Home Price Index - hpidx. This index provides a measure of typical price inflation for houses within the US. Increases in house prices improve the borrower's equity position, which in turn reduces delinquency risk because homeowners are in a better position to refinance or sell if a trigger event occurs. Nationally, house prices peaked in 2007 and declined by 3.3 percent and 4.6 percent in 2008 and 2009, respectively.

Figure 17 captures the growth rate for individuals employed in professional and business services probusvc. It is assumed that these employees are highly trained, have higher income levels, and lower income variation. In the event of job loss, these individuals are likely to find employment more readily. This should reduce the impact of shocks to income and the risk of delinquency. The growth rate for professional and business services employment increased by 204.5 percent between 2004 and 2005 and peaked in 2006. Since 2006, it has declined by 24.1 percent, 34.3 percent, and 290.9 percent in 2007, 2008 and 2009, respectively.

Figure 13: Percent of Applications Denied

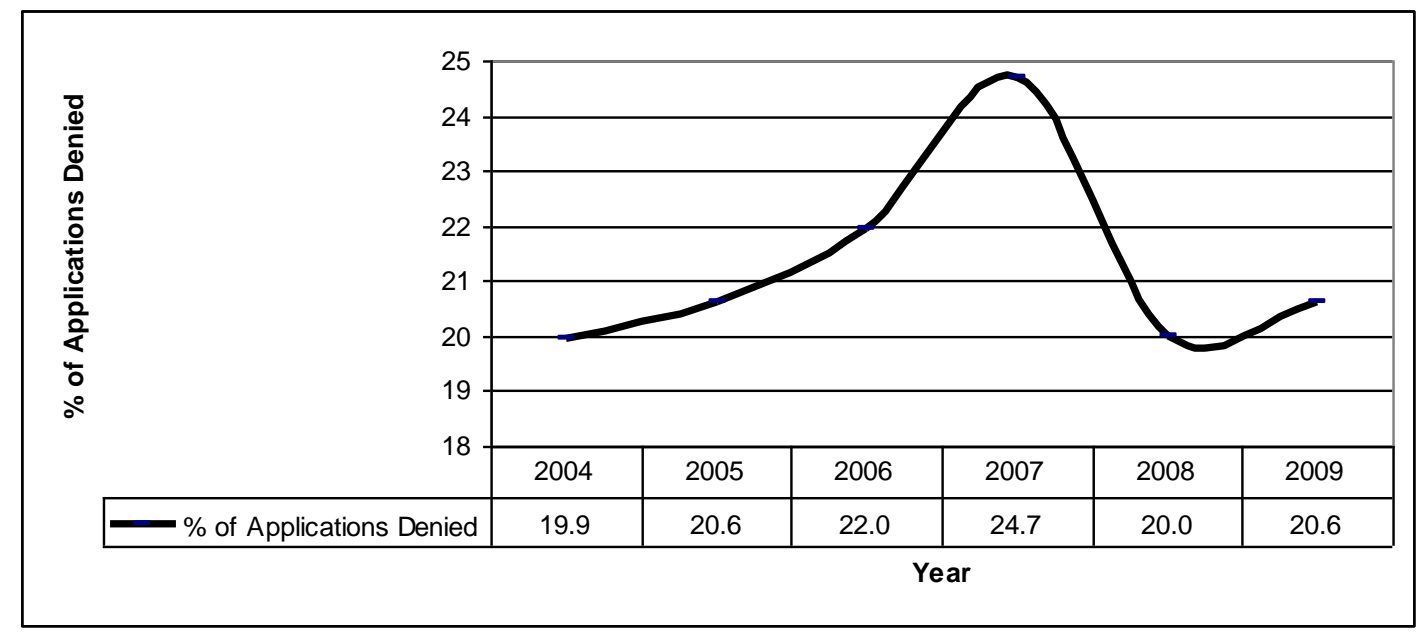


Figure 14: Unemployment Rate

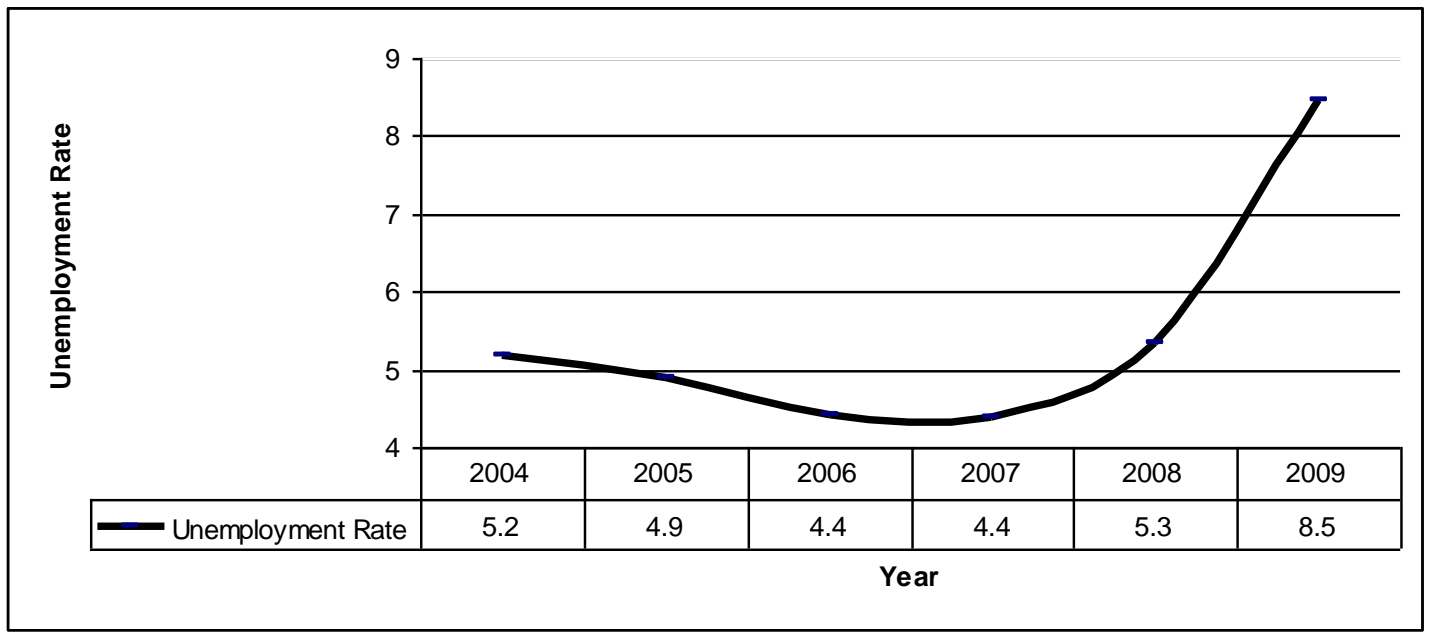

Figure 15: Number of Construction Building Permits

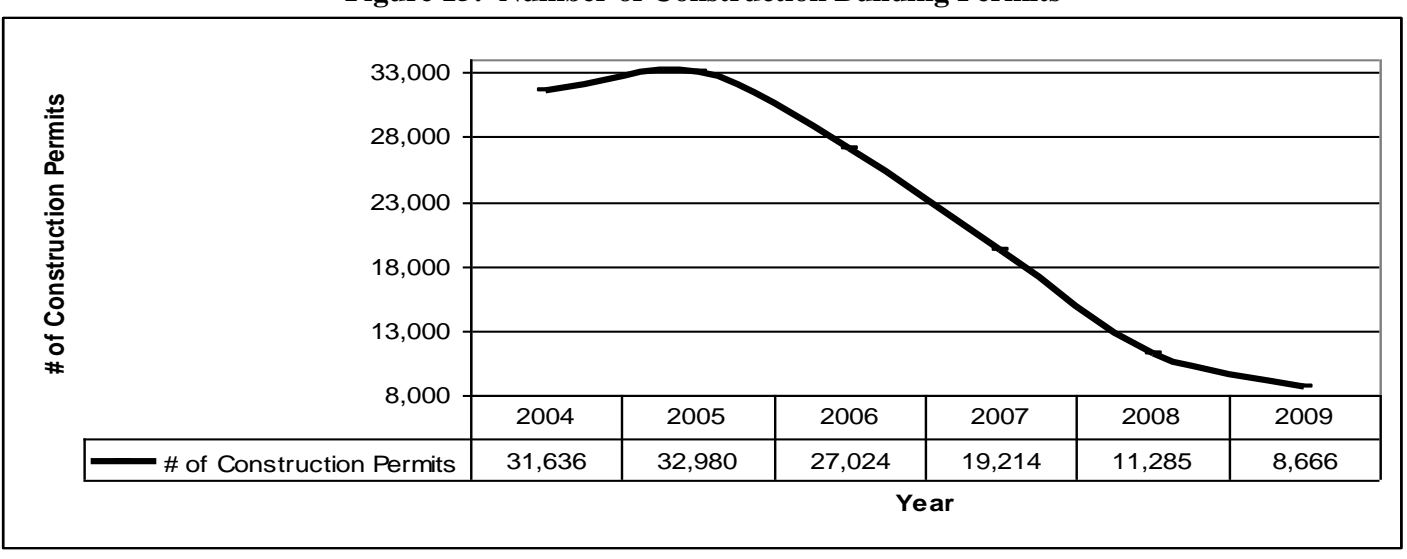

Figure 16: Housing Price Index

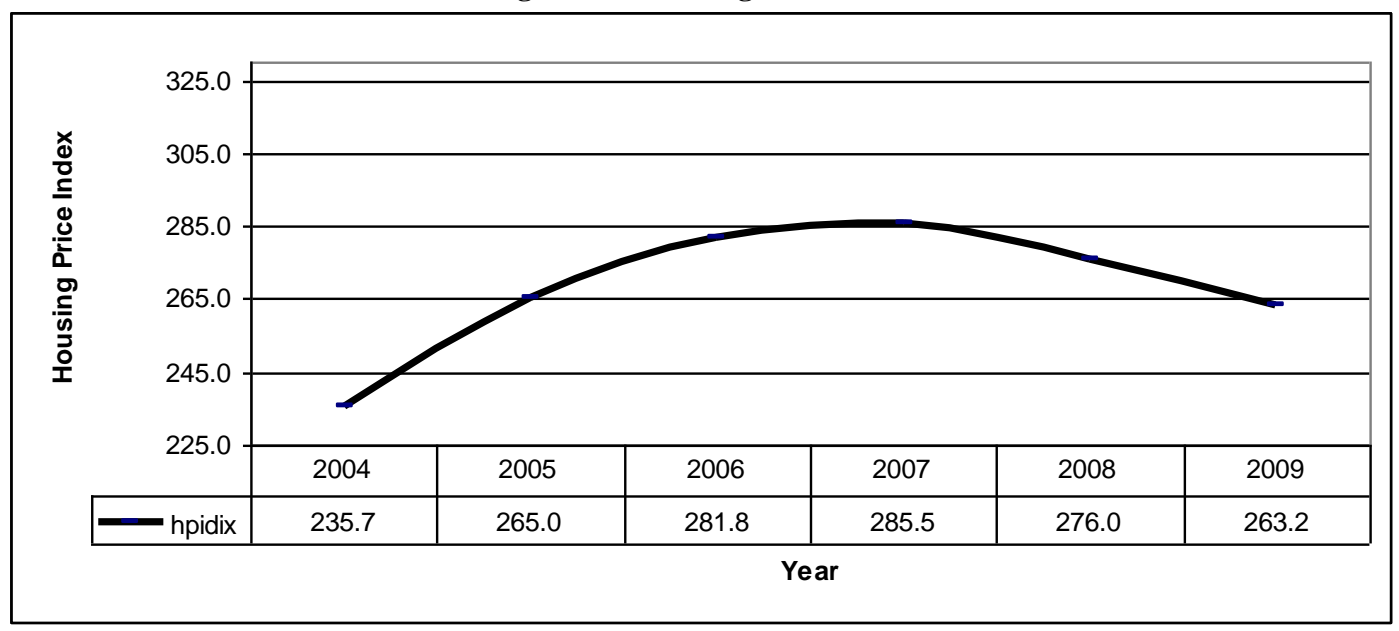


Figure 17: Employment Growth Rate for Professional and Business Services

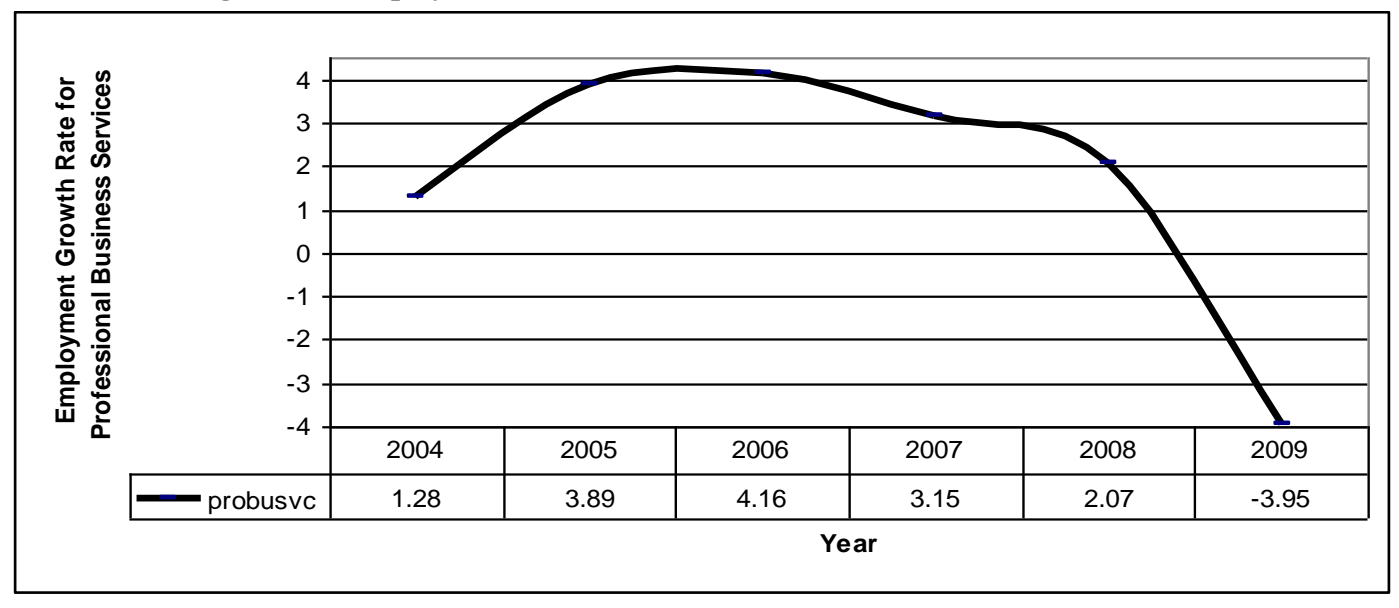

\section{EMPIRICAL ANALYSIS}

Our review of the results focuses on identifying factors that explain delinquency rates for prime and subprime loans. For each type of loan, models are estimated for 30-day, 60-day, 90-day, seriously delinquent (90+ day), and all loans using independent variables that represent: 1) borrower characteristics; 2) loan characteristics; and 3) economic conditions and shocks to income.

Table 2 provides the regression results for prime and subprime 30-day delinquency rates. For both models, $\mathrm{R}^{2}$ exceeds 0.98 . The variable that significantly explains 30 -day delinquency rates for both prime and subprime loans and exhibits the expected direction of influence is house price index (economic condition). For prime loans, the percent of NIV loans and the percent of refinance loans (loan characteristics) significantly explain 30-day delinquency rates. For subprime loans, income (borrower characteristic), percent of non-owner occupied loans, percent of NIV loans, and the percent of refinance loans (loan characteristics) and number of housing permits issued (economic condition) significantly explain 30-day delinquency rates. The regression results suggest the following:

- $\quad 30$-day delinquency rates decrease as the percent of NIV loans increases for prime and subprime loans. NIV loans are primarily approved for borrowers with very high credit scores and sizeable down payments. These loans are considered to be of very high quality with low levels of default risk. Therefore, the regression results seem reasonable.

- $\quad 30$-day delinquency rates increase as the percent of refinance loans increases for prime and subprime loans. This relationship may signify that borrowers who are experienced with mortgage payments may choose to stop making payments temporarily to smooth consumption. Therefore, we would expect to see a positive relationship between percent of refinance loans and 30-day and 60-day delinquency rates and a negative relationship between 90-day and 90+ day delinquency rates because foreclosure filings may proceed after the third payment is missed. Our findings are consistent with this expectation.

- $\quad$ For subprime loans, 30-day delinquency rates increase with borrower income. This relationship may signify that high income borrowers may choose to stop making payments temporarily to smooth consumption. Therefore, the regression results seem reasonable because there is a positive relationship between income and 30-day delinquency rates and no relationship between 60-day, 90-day, and 90+ day delinquency rates.

- $\quad$ For subprime loans, 30-day delinquency rates decrease as the percent of non-owner occupied loans increases. This result may signify that these borrowers view credit impairment that results from skipping mortgage payments to be too costly. Therefore, the regression results seem reasonable.

- $\quad$ For subprime loans, 30-day delinquency rates increase as the number of building permits increase. This result may signify lagged increases in housing inventory leading to falling house prices. This is consistent with studies which demonstrate a rapid buildup of housing stock in subprime neighborhoods followed by dramatic declines in house prices. Therefore, the regression results seem reasonable. 
Table 2: 30-day Delinquency Rates

\begin{tabular}{|c|c|c|c|c|c|c|}
\hline \multirow[b]{2}{*}{ Variable } & \multicolumn{2}{|c|}{ Prime, 30 Days } & & \multicolumn{2}{|c|}{ Subprime, 30 Days } & \\
\hline & Coefficient & t-stat & & Coefficient & t-stat & \\
\hline whpct & -0.0099 & -1.1800 & & -0.0074 & -0.3900 & \\
\hline blpct & -0.0010 & -0.1800 & & 0.0038 & 0.2900 & \\
\hline hispet & 0.0015 & 0.1700 & & -0.0018 & -0.0900 & \\
\hline asnpct & -0.0019 & -0.1000 & & 0.0024 & 0.0500 & \\
\hline ntvpct & 0.0045 & 0.1400 & & 0.1110 & 1.5100 & \\
\hline fempct & -0.0411 & -1.0000 & & -0.0414 & -0.4400 & \\
\hline credscr & -0.0066 & -0.6400 & & 0.0017 & 0.0700 & \\
\hline income & 0.0000 & 0.1800 & & 0.0001 & 2.5700 & $* *$ \\
\hline nonoccpt & -0.0054 & -1.0300 & & -0.0246 & -2.0500 & $* *$ \\
\hline nivst & -0.0470 & -3.7800 & $* * *$ & -0.0839 & -2.9600 & $* * *$ \\
\hline spread & 0.0130 & 1.6500 & & 0.0252 & 1.4100 & \\
\hline pctrefi & 0.0201 & 3.7100 & $* * *$ & 0.0552 & 4.4700 & $* * *$ \\
\hline lien2nd & 0.0028 & 0.3700 & & 0.0272 & 1.5500 & \\
\hline pctadj & 0.0058 & 0.6600 & & 0.0181 & 0.9000 & \\
\hline denpct & -0.0025 & -0.4600 & & 0.0032 & 0.2600 & \\
\hline unempl & 0.0378 & 1.6000 & & -0.0561 & -1.0400 & \\
\hline numpermt & 0.0007 & 0.5600 & & 0.0067 & 2.4900 & $* *$ \\
\hline hpidx & -0.0105 & -9.9800 & $* * *$ & -0.0132 & -5.5300 & $* * *$ \\
\hline probusve & 0.0012 & 0.1800 & & -0.0101 & -0.6700 & \\
\hline R-sq & 0.9928 & & & 0.9801 & & \\
\hline
\end{tabular}

Table 3 provides the regression results for prime and subprime 60-day delinquency rates. For both models, $\mathrm{R}^{2}$ exceeds 0.96 . The variables that significantly explain 60 -day delinquency rates for both prime and subprime loans and exhibit the expected direction of influence are unemployment rate and house price index (economic conditions). Also, income (borrower characteristic) exhibits the expected direction of influence for prime loans. For prime loans, the percent of NIV loans (loan characteristic) and the percent of denials (economic condition) significantly explain 60-day delinquency rates. For subprime loans, the percent of African American borrowers (borrower characteristic), percent of non-owner occupied loans, percent of NIV loans, percent of refinance loans (loan characteristics), percent denials and number of housing permits issued (economic conditions) significantly explain 60-day delinquency rates. The regression results suggest the following:

- 60-day delinquency rates decrease as the percent of NIV loans increases for prime and subprime loans. NIV loans are primarily approved for borrowers with very high credit scores and sizeable down payments. These loans are considered to be of very high quality with low levels of default risk. Therefore, the regression results seem reasonable.

- 60-day delinquency rates increase as the percent of denials increases for prime and subprime loans. Increased denial rates may be capturing an increase in applications from less creditworthy borrowers. Therefore, the regression results seem reasonable.

- $\quad$ For subprime loans, 60-day delinquency rates increase as the percent of African American borrowers increases. This result may signify that African Americans face greater income variation, increasing delinquency risk.

- 60-day delinquency rates increase as the percent of refinance loans increases for subprime loans. This relationship may signify that borrowers who are experienced with mortgage payments may choose to stop making payments temporarily to smooth consumption. Therefore, we would expect to see a positive relationship between percent of refinance loans and 30-day and 60-day delinquency rates and a negative relationship between 90-day and 90+ day delinquency rates because foreclosure filings may proceed after the third payment is missed. Our findings are consistent with this expectation.

- $\quad$ For subprime loans, 60-day delinquency rates decrease as the percent of non-owner occupied loans increases. This result may signify that these borrowers view credit impairment that results from skipping mortgage payments to be too costly. Therefore, the regression results seem reasonable. 
- $\quad$ For subprime loans, 60-day delinquency rates increase as the number of building permits increase. This result may signify lagged increases in housing inventory leading to falling house prices. This is consistent with studies which demonstrate a rapid buildup of housing stock in subprime neighborhoods followed by dramatic declines in house prices. Therefore, the regression results seem reasonable.

Table 3: 60-day Delinquency Rates

\begin{tabular}{|c|c|c|c|c|c|c|}
\hline \multirow[b]{2}{*}{ Variable } & \multicolumn{2}{|c|}{ Prime, 60 Days } & & \multicolumn{2}{|c|}{ Subprime, 60 Days } & \\
\hline & Coefficient & t-stat & & Coefficient & t-stat & \\
\hline whpct & 0.0037 & 0.6000 & & 0.0104 & 0.7500 & \\
\hline blpct & 0.0059 & 1.3800 & & 0.0204 & 2.1600 & $* *$ \\
\hline hispet & -0.0080 & -1.2000 & & -0.0113 & -0.7700 & \\
\hline asnpet & -0.0067 & -0.4700 & & 0.0079 & 0.2500 & \\
\hline ntvpct & -0.0191 & -0.8000 & & -0.0113 & -0.2100 & \\
\hline fempct & -0.0001 & 0.0000 & & -0.0205 & -0.3000 & \\
\hline credscr & 0.0014 & 0.1800 & & -0.0061 & -0.3600 & \\
\hline income & 0.0000 & -2.8100 & $* * *$ & 0.0000 & -0.4000 & \\
\hline nonoccpt & -0.0038 & -0.9700 & & -0.0149 & -1.7200 & $*$ \\
\hline nivst & -0.0270 & -2.9600 & $* * *$ & -0.0694 & -3.4100 & $* * *$ \\
\hline spread & 0.0065 & 1.1300 & & 0.0017 & 0.1300 & \\
\hline pctrefi & 0.0000 & 0.0000 & & 0.0263 & 2.9500 & $* * *$ \\
\hline lien2nd & -0.0075 & -1.3300 & & -0.0084 & -0.6700 & \\
\hline pctadj & 0.0082 & 1.2600 & & 0.0132 & 0.9100 & \\
\hline denpct & 0.0086 & 2.1500 & $* *$ & 0.0295 & 3.3100 & $* * *$ \\
\hline unempl & 0.0519 & 2.9900 & $* * *$ & 0.0855 & 2.2100 & $* *$ \\
\hline numpermt & -0.0005 & -0.5400 & & 0.0038 & 1.9500 & $*$ \\
\hline hpidx & -0.0038 & -4.9700 & $* * *$ & -0.0069 & -4.0100 & $* * *$ \\
\hline probusve & 0.0024 & 0.5000 & & -0.0001 & -0.0100 & \\
\hline R-sq & 0.9624 & & & 0.9925 & & \\
\hline
\end{tabular}

$* * * 1 \%$ significance level; $* * 5 \%$ significance level; * 10\% significance level

Table 4 provides the regression results for prime and subprime 90-day delinquency rates. For both models, $\mathrm{R}^{2}$ exceeds 0.86 . The variable that significantly explains 90 -day delinquency rates for both prime and subprime loans and exhibits the expected direction of influence is unemployment rate (economic condition). Also, income (borrower characteristic), percent of refinance loans, and percent of adjustable rate mortgages (loan characteristics) exhibit the expected direction of influence for prime loans. House price index (economic condition) exhibits the expected direction of influence for subprime loans. For prime and subprime loans, the percent of denials (economic condition) significantly explains 90-day delinquency rates. For subprime loans, the percent of NIV loans (loan characteristic), the percent of Asian American borrowers (borrower characteristic) and the number of building permits (economic condition) significantly explain 90-day delinquency rates. The regression results suggest the following:

- $\quad$ 90-day delinquency rates increase as the percent of denials increases for prime and subprime loans. Increased denial rates may be capturing an increase in applications from less creditworthy borrowers. Therefore, the regression results seem reasonable.

- $\quad$ 90-day delinquency rates decrease as the percent of NIV loans increases for subprime loans. NIV loans are primarily approved for borrowers with very high credit scores and sizeable down payments. These loans are considered to be of very high quality with low levels of default risk. Therefore, the regression results seem reasonable.

- $\quad$ For subprime loans, 90-day delinquency rates increase as the percent of Asian American borrowers increases. This result may signify that Asian Americans face greater income variation, increasing delinquency risk. 
- $\quad$ For subprime loans, 90-day delinquency rates increase as the number of building permits increase. This result may signify lagged increases in housing inventory leading to falling house prices. This is consistent with studies which demonstrate a rapid buildup of housing stock in subprime neighborhoods followed by dramatic declines in house prices. Therefore, the regression results seem reasonable.

Table 4: 90-day Delinquency Rates

\begin{tabular}{|c|c|c|c|c|c|c|}
\hline \multirow[b]{2}{*}{ Variable } & \multicolumn{2}{|c|}{$\begin{array}{l}\text { Prime, } 90 \text { Days } \\
\end{array}$} & & \multicolumn{2}{|c|}{ Subprime, 90 Days } & \\
\hline & Coefficient & t-stat & & Coefficient & t-stat & \\
\hline whpct & 0.0094 & 0.4300 & & 0.0115 & 0.1700 & \\
\hline blpct & 0.0234 & 1.5600 & & 0.0408 & 0.9000 & \\
\hline hispet & -0.0386 & -1.6400 & & -0.0282 & -0.4000 & \\
\hline asnpct & -0.0076 & -0.1500 & & 0.2624 & 1.7200 & $*$ \\
\hline ntvpct & -0.1241 & -1.4800 & & 0.0448 & 0.1800 & \\
\hline fempct & 0.0581 & 0.5400 & & -0.1519 & -0.4700 & \\
\hline credscr & 0.0013 & 0.0500 & & -0.0058 & -0.0700 & \\
\hline income & -0.0002 & -4.3600 & $* * *$ & -0.0001 & -0.7700 & \\
\hline nonoccpt & -0.0064 & -0.4700 & & -0.0548 & -1.3200 & \\
\hline nivst & -0.0521 & -1.6100 & & -0.3008 & -3.0800 & $* * *$ \\
\hline spread & 0.0159 & 0.7800 & & 0.0486 & 0.7900 & \\
\hline pctrefi & -0.0354 & -2.5000 & $* *$ & 0.0419 & 0.9800 & \\
\hline lien2nd & -0.0271 & -1.3500 & & -0.0535 & -0.8800 & \\
\hline pctadj & 0.0402 & 1.7500 & $*$ & 0.0988 & 1.4200 & \\
\hline denpct & 0.0329 & 2.3200 & $* *$ & 0.1373 & 3.2100 & $* * *$ \\
\hline unempl & 0.2760 & 4.4900 & $* * *$ & 0.5867 & 3.1600 & $* * *$ \\
\hline numpermt & -0.0022 & -0.7100 & & 0.0160 & 1.6800 & $*$ \\
\hline hpidx & -0.0039 & -1.4100 & & -0.0370 & -4.4800 & $* * *$ \\
\hline probusve & 0.0072 & 0.4100 & & -0.0229 & -0.4400 & \\
\hline R-sq & 0.8631 & & & 0.9712 & & \\
\hline
\end{tabular}

$* * * 1 \%$ significance level; $* * 5 \%$ significance level; * 10\% significance level

Table 5 provides the regression results for prime and subprime 90+ day delinquency rates. For both models, $\mathrm{R}^{2}$ exceeds 0.94 . The variables that significantly explain $90+$ day delinquency rates for both prime and subprime loans and exhibit the expected direction of influence are unemployment rate, house price index (economic conditions), percent of refinance loans, and percent of adjustable rate mortgages (loan characteristics). Also, income (borrower characteristic) and number of building permits (economic condition) exhibit the expected direction of influence for prime loans. For prime and subprime loans, the percent of denials (economic condition), percent of NIV loans (loan characteristic), and the percent of Hispanic American borrowers (borrower characteristic) significantly explain 90+ day delinquency rates. For prime loans, the percent of Asian and Native American borrowers significantly explain 90+ day delinquency rates. For subprime loans, the percent of loans with subordinate liens (loan characteristic) significantly explains $90+$ day delinquency rates. The regression results suggest the following:

- $\quad 90+$ day delinquency rates increase as the percent of denials increases for prime and subprime loans. Increased denial rates may be capturing an increase in applications from less creditworthy borrowers. Therefore, the regression results seem reasonable.

- $\quad 90+$ day delinquency rates decrease as the percent of NIV loans increases for prime and subprime loans. NIV loans are primarily approved for borrowers with very high credit scores and sizeable down payments. These loans are considered to be of very high quality with low levels of default risk. Therefore, the regression results seem reasonable.

- $\quad 90+$ day delinquency rates decrease as the percent of Hispanic American borrowers increase for prime and subprime loans. This finding may signify that lenders pursue foreclosure more rapidly with these borrowers. Otherwise, these borrowers may attempt to avoid prolonged delinquency because of the credit impairment associated with foreclosure. 
- $\quad 90+$ day delinquency rates decrease as the percent of Asian and Native American borrowers increase for prime loans. This finding may signify that lenders pursue foreclosure more rapidly with these borrowers. Otherwise, these borrowers may attempt to avoid prolonged delinquency because of the credit impairment associated with foreclosure.

- $\quad 90+$ day delinquency rates decrease as the percent of loans with subordinate liens increases for subprime loans. This finding may signify that lenders pursue foreclosure more rapidly for these borrowers.

Table 5: 90+ Day Delinquency Rates

\begin{tabular}{|c|c|c|c|c|c|c|}
\hline \multirow[b]{2}{*}{ Variable } & \multicolumn{2}{|c|}{ Prime, 90+ Days } & & \multicolumn{2}{|c|}{ Subprime, 90+ Days } & \\
\hline & Coefficient & t-stat & & Coefficient & t-stat & \\
\hline whpct & 0.0081 & 0.2900 & & 0.0770 & 0.8200 & \\
\hline blpct & 0.0254 & 1.3600 & & 0.0292 & 0.4500 & \\
\hline hispct & -0.1060 & -3.6200 & $* * *$ & -0.3656 & -3.6400 & $* * *$ \\
\hline asnpct & -0.1442 & -2.2900 & $* *$ & -0.0412 & -0.1900 & \\
\hline ntvpct & -0.2184 & -2.0800 & $* *$ & -0.1290 & -0.3600 & \\
\hline fempct & 0.1601 & 1.2000 & & 0.1634 & 0.3600 & \\
\hline credscr & 0.0160 & 0.4800 & & 0.0689 & 0.6000 & \\
\hline income & -0.0002 & -3.5700 & $* * *$ & 0.0002 & 0.8900 & \\
\hline nonoccpt & 0.0165 & 0.9700 & & 0.0560 & 0.9500 & \\
\hline nivst & -0.0952 & -2.3600 & $* *$ & -0.6156 & -4.4400 & $* * *$ \\
\hline spread & 0.0129 & 0.5100 & & -0.0182 & -0.2100 & \\
\hline petrefi & -0.0598 & -3.3900 & $* * *$ & -0.1004 & -1.6600 & $*$ \\
\hline lien2nd & -0.0291 & -1.1700 & & -0.1999 & -2.3300 & $* *$ \\
\hline pctadj & 0.1144 & 3.9900 & $* * *$ & 0.4016 & 4.0900 & $* * *$ \\
\hline denpct & 0.0482 & 2.7300 & $* * *$ & 0.2857 & 4.7200 & $* * *$ \\
\hline unempl & 0.4523 & 5.9000 & $* * *$ & 1.1648 & 4.4200 & $* * *$ \\
\hline numpermt & -0.0100 & -3.4800 & $* * *$ & -0.0200 & -1.3700 & \\
\hline hpidx & -0.0116 & -3.4000 & $* * *$ & -0.0502 & -4.2900 & $* * *$ \\
\hline probusve & -0.0051 & -0.2400 & & -0.0176 & -0.2400 & \\
\hline R-sq & 0.9433 & & & 0.9801 & & \\
\hline
\end{tabular}

*** $1 \%$ significance level; ** 5\% significance level; * 10\% significance level

Table 6 provides the regression results for all prime and subprime delinquency rates. For both models, $\mathrm{R}^{2}$ exceeds 0.96. The variables that significantly explain delinquency rates for both prime and subprime loans and exhibit the expected direction of influence are unemployment rate and house price index (economic conditions). Also, income (borrower characteristic) exhibits the expected direction of influence for prime loans. For prime and subprime loans, the percent of denials (economic condition) and the percent of NIV loans (loan characteristic) significantly explain delinquency rates. For subprime loans, the percent of Asian borrowers (borrower characteristic) and the number of building permits (economic condition) significantly explain delinquency rates. The regression results suggest the following:

- delinquency rates increase as the percent of denials increases for prime and subprime loans. Increased denial rates may be capturing an increase in applications from less creditworthy borrowers. Therefore, the regression results seem reasonable.

- delinquency rates decrease as the percent of NIV loans increases for prime and subprime loans. NIV loans are primarily approved for borrowers with very high credit scores and sizeable down payments. These loans are considered to be of very high quality with low levels of default risk. Therefore, the regression results seem reasonable.

- delinquency rates increase as the percent of Asian American borrowers increases for subprime loans. This result may signify that Asian Americans face greater income variation, increasing delinquency risk. 
- $\quad$ delinquency rates increase as the number of building permits increases for subprime loans. This result may signify lagged increases in housing inventory leading to falling house prices. This is consistent with studies which demonstrate a rapid buildup of housing stock in subprime neighborhoods followed by dramatic declines in house prices. Therefore, the regression results seem reasonable.

Table 6: Delinquency rates (all delinquent loans)

\begin{tabular}{|c|c|c|c|c|c|c|}
\hline \multirow[b]{2}{*}{ Variable } & \multicolumn{3}{|c|}{ Prime Loans } & \multicolumn{3}{|c|}{ Subprime Loans } \\
\hline & Coefficient & t-stat & & Coefficient & t-stat & \\
\hline whpct & 0.0038 & 0.11 & & 0.0115 & 0.17 & \\
\hline blpct & 0.0291 & 1.29 & & 0.0408 & 0.90 & \\
\hline hispet & -0.0445 & -1.26 & & -0.0282 & -0.40 & \\
\hline asnpct & -0.0162 & -0.21 & & 0.2624 & 1.72 & $*$ \\
\hline ntvpet & -0.1427 & -1.13 & & 0.0448 & 0.18 & \\
\hline fempct & 0.0138 & 0.09 & & -0.1519 & -0.47 & \\
\hline credscr & -0.0097 & -0.24 & & -0.0058 & -0.07 & \\
\hline income & -0.0002 & -3.36 & $* * *$ & -0.0001 & -0.77 & \\
\hline nonoccpt & -0.0151 & -0.73 & & -0.0548 & -1.32 & \\
\hline nivst & -0.1224 & -2.52 & $* *$ & -0.3008 & -3.08 & $* * *$ \\
\hline spread & 0.0335 & 1.09 & & 0.0486 & 0.79 & \\
\hline pctrefi & -0.0147 & -0.69 & & 0.0419 & 0.98 & \\
\hline lien2nd & -0.0294 & -0.98 & & -0.0535 & -0.88 & \\
\hline pctadj & 0.0523 & 1.52 & & 0.0988 & 1.42 & \\
\hline denpct & 0.0391 & 1.84 & $*$ & 0.1373 & 3.21 & $* * *$ \\
\hline unempl & 0.3758 & 4.07 & $* * *$ & 0.5867 & 3.16 & $* * *$ \\
\hline numpermt & -0.0020 & -0.42 & & 0.0160 & 1.68 & $*$ \\
\hline hpidx & -0.0179 & -4.37 & $* * *$ & -0.0370 & -4.48 & $* * *$ \\
\hline probusve & 0.0103 & 0.40 & & -0.0229 & -0.44 & \\
\hline R-sq & 0.9668 & & & 0.9933 & & \\
\hline
\end{tabular}

$* * * 1 \%$ significance level; $* * 5 \%$ significance level; $* 10 \%$ significance level

Overall, the factors that significantly influence delinquency rates are:

- Borrower characteristics - Income reduces all delinquency rates for prime borrowers, except 30-day delinquency rates.

- $\quad$ Loan characteristics - NIV loans reduce delinquency rates. ARMs increase 90-day delinquency rates for prime loans and 90+ day delinquency rates for prime and subprime loans. Refinance loans increase 30- and 60-day delinquency rates and reduce 90-day and 90+ day delinquency rates.

- $\quad$ Economic conditions - Growth in the house price index reduces delinquency rates. Unemployment and denials increase all delinquency rates, except 30-day delinquency rates.

These results suggest that borrower income, type of loan, and the general health of the economy remain important in determining delinquency risk. Also, factors that determine 30- and 60-day delinquency rates differ from those that determine 90-day and 90+ day delinquency rates. Economic conditions such as unemployment rate and denials do not affect 30-day delinquency rates. However, these factors are important in explaining 60-day, 90day and 90+ day delinquency rates. Similarly, refinance loans increase 30- and 60-day delinquency rates and reduce 90-day and 90+ day delinquency rates. This suggests that borrowers with experience making mortgage payments may temporarily skip payments but will avoid the risk of foreclosure by catching up when the third payment is due. Also, factors that determine prime delinquency rates differ from those that determine subprime delinquency rates. Income reduces prime loan delinquency rates, except for 30-day delinquencies. However, income is only significant in explaining 30-day delinquency rates for subprime loans and the relationship is positive. Also, the number of building permits increases subprime loan delinquency rates, except for $90+$ day delinquencies. However, the number of building permits is only significant in explaining 90+ day delinquency rates for prime loans and the relationship is negative. Finally, borrower race does not consistently explain delinquency rates. In some cases, 
borrower race increases delinquency rates and in other cases borrower race reduces delinquency rates.

\section{CONCLUSIONS}

The Obama Administration's efforts to curve the devastating effects of forced foreclosure have been introduced in the President's Home Affordable Modification "Relief" Plan of March 4, 2009. The Plan addresses many issues presented in this paper. For mortgage loans that are in imminent default, loan modifications will be used as an effective tool to minimize losses to investors and help borrowers avoid foreclosure. The Plan reduces individual mortgage interest rates by as much as 200 basis points, extends the term of many of the mortgages up to as many as 40 years and, where possible, allows for forbearance or forgiveness of portions of mortgage principal balances to allow some mortgage payments to equal to thirty-one percent of the monthly household income. The incentive of the plan is to bring "responsible" homeowners to a current status on their mortgage loans and allow them to remain in their homes, to reduce the large number of foreclosures, and to assist homeowners in maintaining some remnants of their prior credit standing and avoid delinquencies and foreclosures.

\section{AUTHOR INFORMATION}

Dr. Bill Brent, DBA, is an Associate Professor of Finance in the Department of Finance, International Business and Real Estate at Howard University. On active duty he has served as Controller, Naval Hospital Quantico, Virginia and National Naval Medical Center, Bethesda, MD. He has additionally been Financial Planner for Blue Cross/Shield and Financial Systems Coordinator for at Georgetown University Hospital. His research efforts have focused on M\&A Case Analysis, and Capital Structure analysis as Associate Editor, Journal of Financial Case Research; foreclosures, financial literacy as Principal Investigator for the Howard University's research efforts.

Dr. Lynne Kelly is an Assistant Professor in the Department of Finance, International Business and Insurance at Howard University in Washington, DC. She conducts research in the areas of real estate, international finance, and mutual fund performance.

Debby Lindsey-Taliefero, Ph.D. is an Associate Professor of Economics in the Department of Finance at Howard University. Her research efforts have focused on mortgage lending, foreclosures, financial literacy, and discrimination in auto financing. Her work has been featured or cited by ABC 20/20, New York Times, Washington Post, and in a DOJ's Amicus brief- auto finance litigation. Prior to Howard, she worked as an economist for ComplianceTech, Anser; the Federal Emergency Management Agency; the National Urban League, and the NAACP

Dr. Price joined the Howard University faculty in Fall 2006. He teaches courses in Macroeconomics, Financial Management, Finance Principles, Financial Modeling, Financial Markets/Institutions and Commercial Real Estate/Housing Finance. He also serves as a faculty advisor of the Howard University Real Estate Club. He holds a B.S. in Civil Engineering from Cornell University in Ithaca, NY and a Ph.D. in Finance from The Florida State University in Tallahassee, FL. His research interests include real estate finance, asset pricing, valuation, mutual funds, mortgage pricing and REITs. His research appears in the Journal of Real Estate Research and Journal of Real Estate Portfolio Management

\section{REFERENCES}

1. Ambrose, Brent W. and Charles A. Capone, "Modeling the Conditional Probability of Foreclosure in the Context of Single-Family Mortgage Default Resolutions", Real Estate Economics, 1998

2. Campbell, Tim S. and J. Kimball Dietrich, "The Determinants of Default on Insured Conventional Residential Mortgage Loans", Journal of Finance, 1983

3. Capone, C.A., "Research into Mortgage Default and Affordable Housing: A Primer", Local Initiatives Support Corporation, 2002

4. Capozza, Dennis R. and Thomas A. Thomson, "Optimal Stopping and Losses on Subprime Mortgages", Journal of Real Estate Finance and Economics, 2005

5. Capozza, Dennis R. and Thomas A. Thomson, "Subprime Transitions: Lingering or Malingering in Default?", Journal of Real Estate Finance and Economics, 2006 
6. Danis, Michelle A. and Anthony Pennington-Cross, "A Dynamic Look at Subprime Loan Performance", Journal of Fixed Income, 2005

7. $\quad$ Greene, W.H., "Econometric Analysis", $5^{\text {th }}$ ed. Upper Saddle River, NJ: Prentice Hall, 2003

8. Herzog, J.P. and J.S. Earley, "Home Mortgage Delinquency and Foreclosure", Cambridge, MA: National Bureau of Economic Research, 1970

9. Morton, T. Gregory, “A Discriminant Function Analysis of Residential Mortgage Delinquency and Foreclosure", Real Estate Economics, 1975

10. von Furstenberg, George M. and R. Jeffrey Green, "Estimation of Delinquency Risk for Home Mortgage Portfolios", Real Estate Economics, 1974

11. Webb, Bruce G., "Borrower Risk Under Alternative Mortgage Instruments", Journal of Finance, 1982 
NOTES 